\title{
Separation of coriander seeds by Red, Green and Blue image processing
}

\author{
Isabella Brandão Moreira $^{1^{*}}$ (D) Rita de Cassia Mota Monteiro ${ }^{2}$ (D) \\ Raimunda Nonata Oliveira da Silva ${ }^{2}$ (i) Nander Ferraz Hornke ${ }^{2}$ (i) \\ Ádamo de Sousa Araújo ${ }^{1}$ (D) Gizele Ingrid Gadotti ${ }^{1}$ (D)
}

${ }^{1}$ Centro de Engenharias, Universidade Federal de Pelotas (UFPel). 96075-810. Pelotas, RS, Brasil. E-mail: isabella.moreira@edu.ufpel.br. ${ }^{*}$ Corresponding author.

${ }^{2}$ Pós-graduação em Ciência e Tecnologia de Sementes, Universidade Federal de Pelotas (UFPel). Pelotas, RS, Brasil.

ABSTRACT: Coriander seeds have high socio-economic value in several regions of Brazil, especially in the North and Northeast. Seed maturation determined by color influences the seed quality. With this, digital image processing has become an important tool for separating seeds by color since this classification is usually performed by humans and is highly susceptible to error. The study established parameters for separating coriander seeds by red green and blue (RGB) image analysis, seeking a better selection of coriander seeds according to their color, and evaluating the physiological quality by the germination test. Separation was carried out from two coriander seed lots to obtain samples of $20 \mathrm{~g}$ each in three shades: yellowish, gray, and mixed. Images were acquired by the HP C4480 Scanner and processed in the MATLAB software; then, a histogram was constructed for each color analyzed in each sample by the RGB system. ANOVA tested the averages of the scales to ratify the difference in the components' distributions. The germination test was performed to confirm the results of seed separation using image analysis. The best selection of coriander seeds was achieved by the blue scale, and the germination test indicated that yellow seeds have a higher physiological quality than brownish/greyish seeds.

Key words: MATLAB, color, seed selection, physiological quality.

Separação de sementes de coentro por processamento de imagens Red, Green e Blue

RESUMO: As sementes de coentro possuem alto valor socioeconômico em diversas regiões do Brasil, especialmente no Norte e Nordeste. A maturação de sementes determinada pela coloração influencia a qualidade da semente. Com isso, o processamento digital de imagens se tornou uma importante ferramenta para separação de sementes por meioda sua coloração, tendo em vista que essa separação normalmente é realizada por humanos e está altamente suscetível ao erro. O estudo tem como objetivo estabelecer parâmetros para separação de sementes de coentro por meio de processamento de análises de imagem red green and blue (RGB), buscando uma melhor seleção de sementes de coentro em função da sua coloração, assim como, avaliar a qualidade fisiológica por meio do teste de germinação. A partir de dois lotes de sementes de coentro, realizou-se a separação para obter amostras de $20 \mathrm{~g}$ cada, em três tonalidades: amareladas, cinzas e mistas. As imagens foram adquiridas através da Scanner HP C4480 e processadas através do programa MATLAB, em seguida gerou-se um histograma para cada coloração analisada em cada amostra, por meio do sistema RGB. Na sequência, os resultados das médias das escalas foram analisados por ANOVA com a finalidade de ratificar a diferença das distribuições das componentes. Realizou-se o teste de germinação para ratificar os resultados da separação de sementes de coentro por meio de análises de imagens. A melhor seleção das sementes de coentro ocorreu através da escala em azul e o teste de germinação indicou que as sementes amarelas possuem qualidade fisiológica superior as sementes amarronzadas/acinzentadas.

Palavras-chave: MATLAB, coloração, seleção de sementes, qualidade fisiológica.

\section{INTRODUCTION}

Coriander (Coriandrum sativum) is a species belonging to the family Apiaceae, which has great value and commercial importance. Its seeds are widely consumed in several regions of Brazil, especially in the North and Northeast (WANDERLEY JÚNIOR; NASCIMENTO, 2008; SOUZA et al., 2011). Seed maturation is one of the physiological quality parameters, being a crucial point for the health and vigor of plants, which can be determined by seed coat color (HEMENDER et al., 2018; JUSTINO et al., 2015). According to Embrapa Pantanal (VAZ, 2007), coriander seeds are ready to be harvested when about $50-60 \%$ fruits are golden yellow or light brown, depending on the variety. In agreement with COŞKUNER \& KARABABA (2007), coriander seeds must have uniform color and no stains as a characteristic. After drying, seeds are mostly brown, and may also vary between green, strawy or whitish. As manual seed

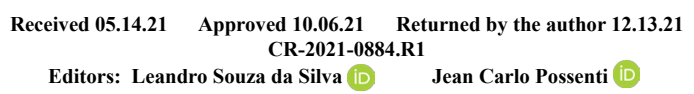


separation analysis methods are extremely exhausting and highly susceptible to failures, they have been replaced by image analysis technologies, especially in the post-harvest process (SANTANNA et al., 2014; HEMENDER et al., 2018). Image processing makes use of algorithms to extract objects, which can be developed with the help of several tools, including Matlab Mathematical ${ }^{\circledR}$ (ARAÚJO et al., 2015; MONTEIRO et al., 2019).

Concomitantly, the RGB (Red, Green and Blue) system is used for seed selection bycolor using digital images. The smallest dot composing a digital image that contains color is the pixel, basic unit for digital images, as well as the entirety of a grouping of pixels constitutes an entire image. This method is characterized by each pixel having a three-dimensional space containing the three primary colors: red, green and blue, in which each color has 256 shades, thus being able to obtain 16.7 million colors ( $256 \times 256 \times 256)$, in which the interpolation of these colors generates a single color for each pixel (BARBOSA et al., 2016).

Coriander is widely consumed in Brazil and despite its economic importance (SOUZA et al., 2011), there are still few data and studies related to the color of its coat, indicating the need for furtherstudies.

This study established coriander seed separation parameters by RGB image analysis, seeking a better selection of seeds according to color. As well as evaluating its physiological quality by the germination test.

\section{MATERIALS AND METHODS}

Image processing was performed at the Agrotechnology Laboratory, Engineering Center, Federal University of Pelotas, Capão do Leão Campus, Pelotas, state of Rio Grande do Sul. From two lots of Verdão coriander seeds, called Lot 1 (Figure 1) and Lot 2 (Figure 2), manual separation was performed to obtain samples with $20 \mathrm{~g}$ seeds each (around 2,000 seeds per sample), in three shades, which are yellow, gray and mixed.

Images were obtained by the HP Scanner C4480, basing its methodology on image capture. Seeds were delimited by a rectangle of white drawing sheet, with $5 \times 7 \mathrm{cmdimensions,} \mathrm{and} \mathrm{with} \mathrm{a} \mathrm{background}$ of the same material and the same color. Previously, background colors were tested, of which white was the most suitable. Then, images were introduced and processed in MATLAB (Student License), with script in algorithmic language (Figure 3), according to MONTEIRO et al. (2019).

Through the script, a histogram was constructed for each color analyzed in each sample, through color bands (grey, red, green and blue scale) and graphs were produced and averages were calculated for each color, thus, we obtained a single frequency value for each lot. For statistical analysis, a completely randomized experimental design was used, considering as repetition the averages found through the color bands. Afterwards, the results of

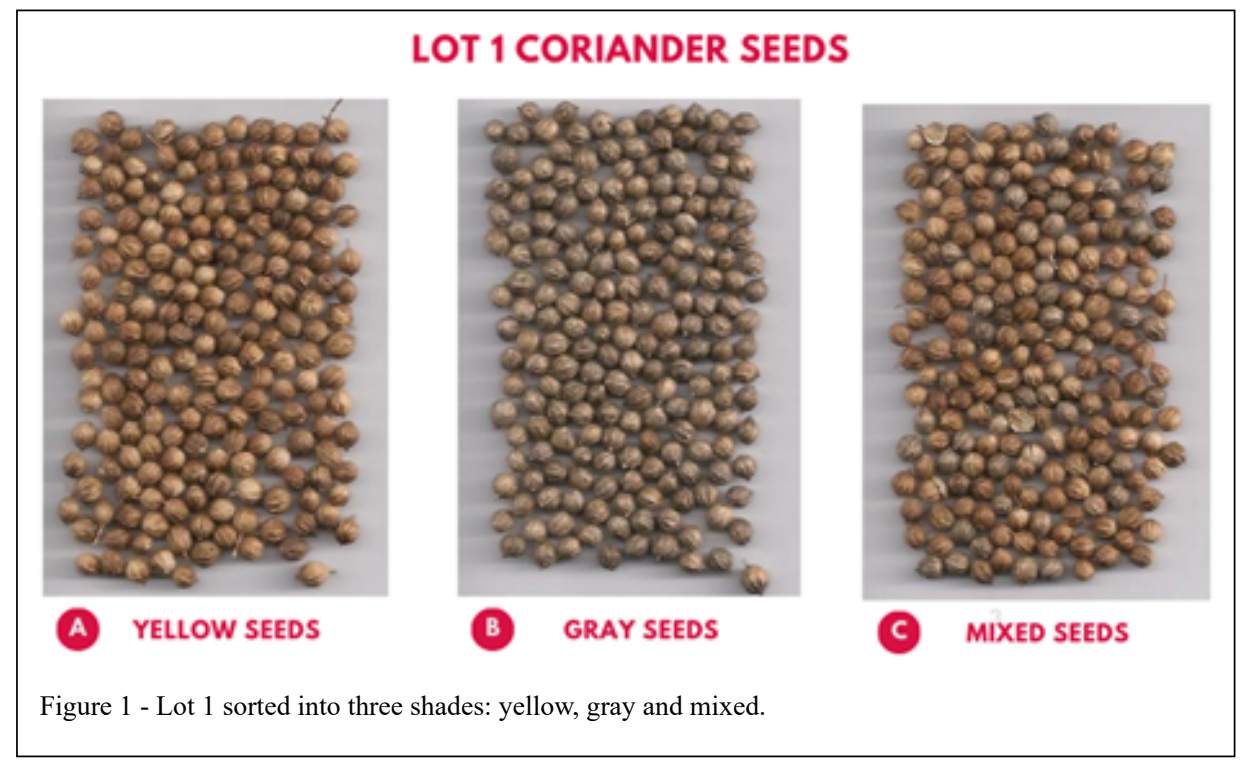

Ciência Rural, v.52, n.9, 2022. 


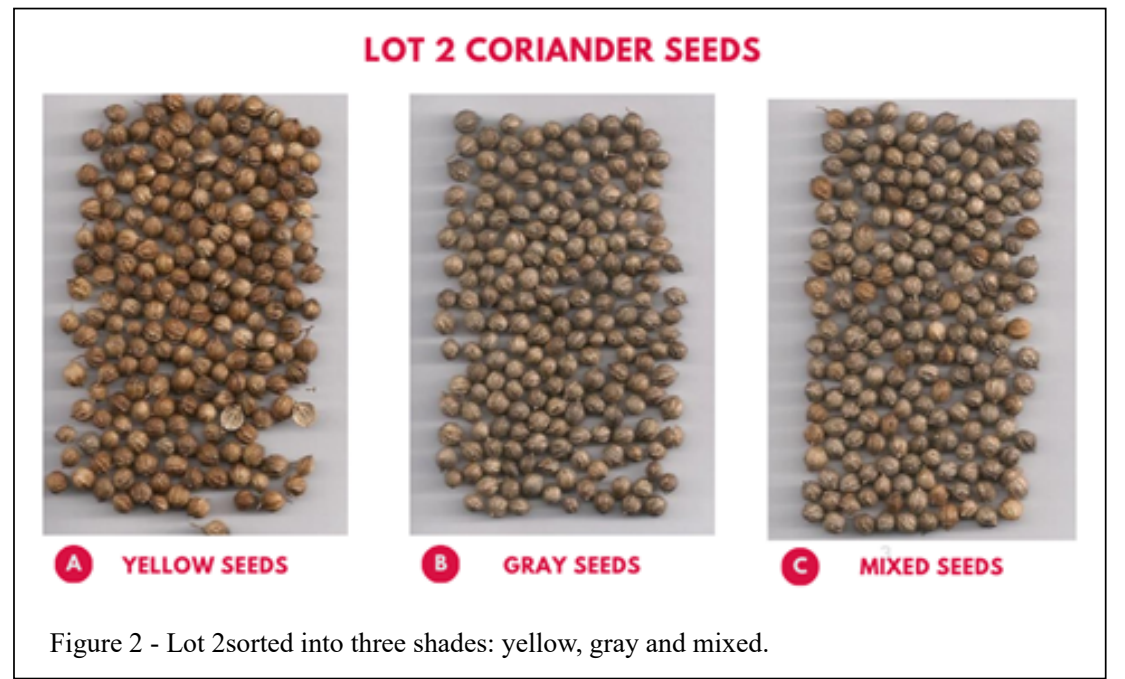

the averages of the scales were analyzed by ANOVA in order to ratify the difference in the distributions of the components.

After digitally processing the images, coriander seeds were subjected to germination test at the Laboratório Didático de Análise de Sementes "Flávio Farias Rocha", at the Faculdade de Agronomia Eliseu Maciel, Universidade Federal de Pelotas (UFPEL), at Capão do Leão Campus, Pelotas, state of Rio Grande do Sul, Brazil.

Coriander seeds $(n=200)$ were placed in a plastic Gerbox and pleated germitest paper moistened to $2.5 \mathrm{x}$ their mass, using 50 seeds per subsample. Then, seeds were taken to the germinator, at $20^{\circ} \mathrm{C}-30$ ${ }^{\circ} \mathrm{C}$, for 21 days for the germination test, according to RAS. The first germination count (PCG) was performed on the seventh day after sowing, also according to RAS (BRASIL, 2009).

For statistical analysis, a completely randomized design with four replications was used. The collected data were tested by ANOVA at 5\% significance and subjected to comparison of means by Tukey's test, at a probability level of 5\%, using the Sisvar software.

\section{RESULTS AND DISCUSSION}

In Lot 1 (Figure 4), the frequency values demonstrated that the blue scale shows a significant

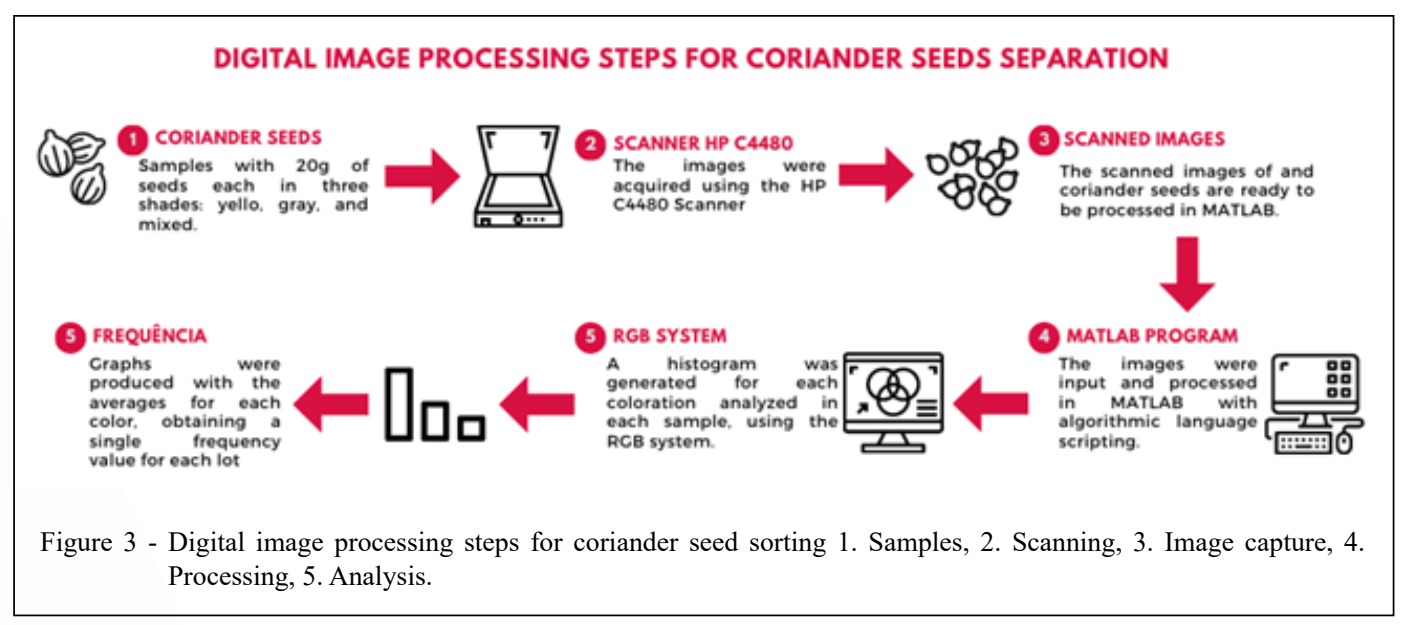

Ciência Rural, v.52, n.9, 2022. 


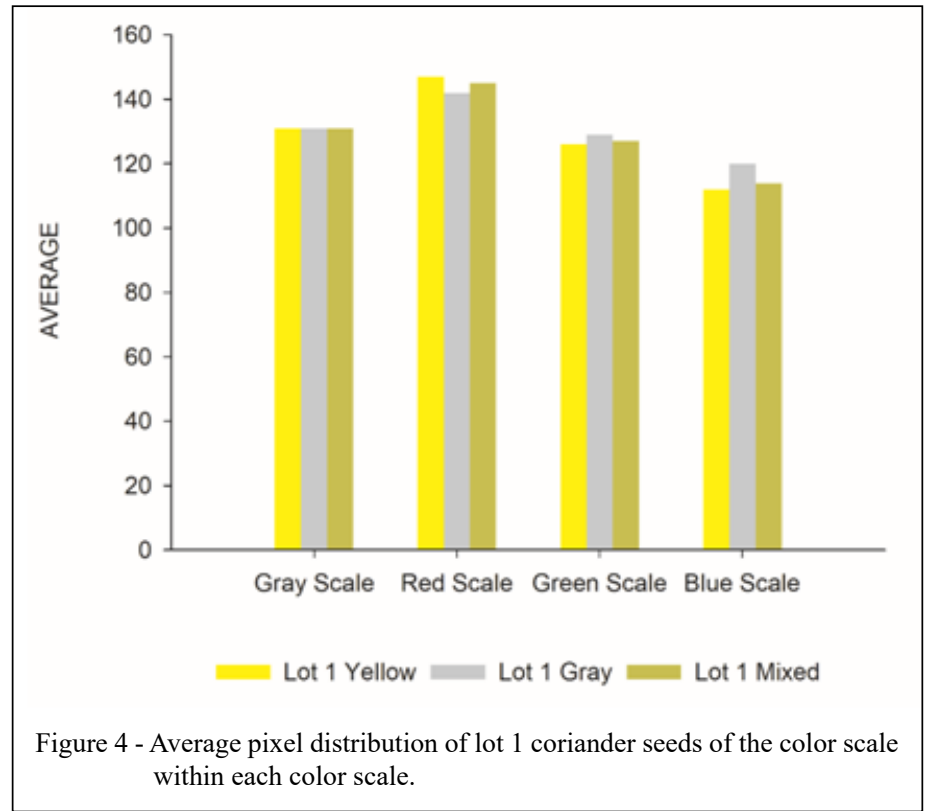

variation between lots, thus enhancing the difference between all scales. While, in Lot 2 (Figure 5), the significant frequency variation is demonstrated in the green and blue scales, contrasting with the other scales.

In the ANOVA analysis, the gray scale in Lot 1 showed no separation (Table 1). The red scale separated the lots; however, the green as well as the blue scale could be used for the separation as they have the same trend. Table 1 and figures 4 and 5 show that the blue scale is the most suitable for separating the lots due to greater differences in pixel frequencies and the separation of colors by ANOVA in both lots.

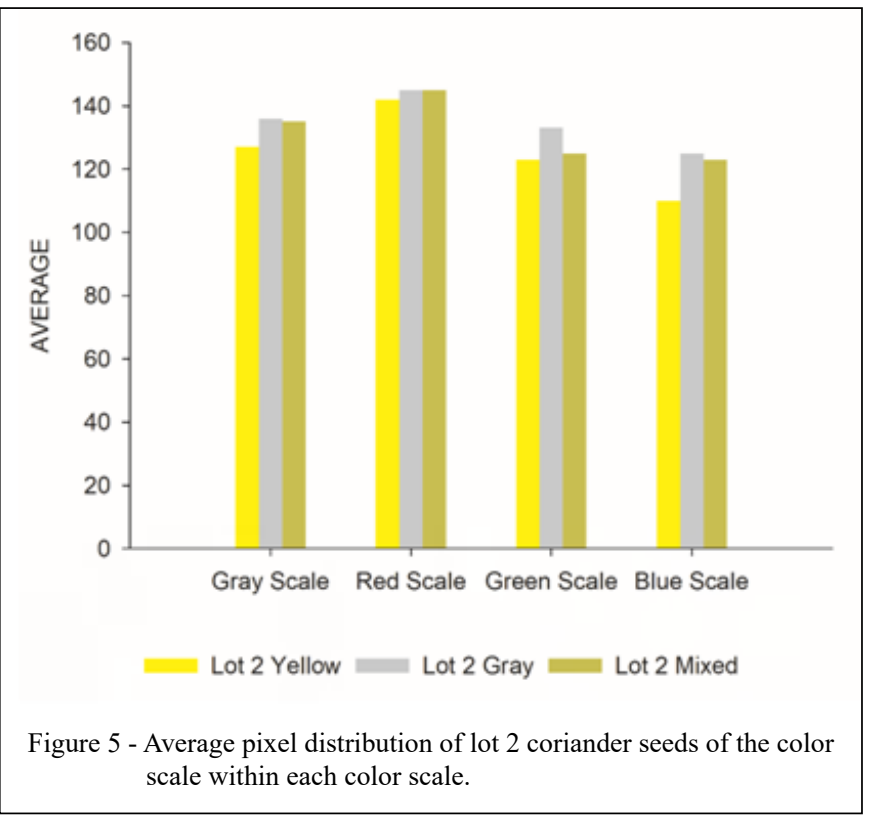

Ciência Rural, v.52, n.9, 2022. 
Table1 - Mean values of yellow, gray and mixed coriander seeds oflot 1as a function of color scales.

\begin{tabular}{|c|c|c|c|c|}
\hline & Gray scale & Red scale & Green scale & Blue scale \\
\hline Lot 1 Yellow & 131 a B & 147 a A & $126 \mathrm{c} \mathrm{C}$ & 112 c D \\
\hline Lot 1 Gray & 131 a B & 142 c A & 129 a C & 120 a D \\
\hline Lot 1 Mixed & 131 a B & $145 \mathrm{~b} \mathrm{~A}$ & $127 \mathrm{~b} \mathrm{C}$ & 114 b D \\
\hline
\end{tabular}

"mean values followed by different lowercase letters, in the same column, are significantly different by Tukey’s test at $5 \%$ probability.

The red scale in Lot 2 (Table 2) showed no similar separation between Lot 2 gray and Lot 2 mixed. The gray, green and blue scales have the same trend. However, again, ANOVA evidenced that the blue scale is the most suitable for separating the lots, due to the contrast between the samples.

It can be concluded that the blue scale is the most interesting for coriander separation. The gray scale, the most used in color sorting machines, may not be the most effective. And a grayscale machine can be easily adapted to RGB colors.

In their study, MONTEIRO et al. (2019) on the classification of rice defects (heat damage, chalky, stained and broken and husk rice) indicated intermediate values, concluding that there is a possibility of using other color scales for selection of rice defects. The blue scale can separate chalky kernels in either white or parboiled rice. The green scale can be used to separate different defects in parboiled rice and the red scale is not suitable for separating different defects in white or parboiled rice. To identify damage to soybean seeds, MONTEIRO et al. (2021) concluded that the red scale is more interesting for greenish seeds.

In order to quantify the areas that present stains on coffee seeds, it is necessary to perform the LERCAFE test, where the seeds are immersed in a sodium hypochlorite solution for a present time and temperature. As this is a visual assessment, RIBEIRO et al. (2016) used image processing to make this classification through Fisher's linear discriminant function, concluding the method's potential efficiency.

As for physiological quality, table 3 lists the results of the germination percentage and the first germination count. In both lots, the yellow seeds had higher values for germination percentage and first germination count, indicating higher physiological quality, in contrast to the gray seed lot. This is because yellowish coriander seeds are less deteriorated than brown/gray seeds, as the latter have this color because they remain in the field exposed to adverse weather conditions for a long period. Broken coriander seeds had a more brownish color, according to NASCIMENTO et al. (2006), due to exposure to weather for a longer period in manual harvesting.

When comparing the separation by physiological quality (germination and first germination count) and the separation by the color component, the trends of the gray, green and blue color components are similar. The ash must be excluded, because in a specific lot, this component was not efficient.

In a study by RIBEIRO et al. (2013), white clover seeds with red-yellow coat performed well

Table 2 - Mean values of yellow, gray and mixed coriander seeds of lot 2 as a function of color scales.

\begin{tabular}{|c|c|c|c|c|}
\hline & Gray scale & Red scale & Green scale & Blue scale \\
\hline Lot 2Yellow & 127 c B & 142 b A & 123 c C & 110 c D \\
\hline Lot 2 Gray & 136 a B & 145 a A & 133 a C & 125 a D \\
\hline Lot 2Mixed & $135 \mathrm{~b} \mathrm{~B}$ & 145 a A & $125 \mathrm{~b} \mathrm{C}$ & $123 \mathrm{~b} \mathrm{D}$ \\
\hline
\end{tabular}

"mean values followed by different lowercase letters, in the same column, are significantly different by Tukey's test at $5 \%$ probability. 
Table 3 - Mean values of germination and first germination count (FGC) of yellow, gray and mixed coriander seeds of Lot 1 and Lot 2.

\begin{tabular}{|c|c|c|c|c|}
\hline \multirow[t]{2}{*}{ COLOR } & \multicolumn{2}{|c|}{--------------\% Germination-------------- } & \multicolumn{2}{|c|}{--------------------'FGC--------------- } \\
\hline & Lote 1 & Lote 2 & Lote 1 & Lote 2 \\
\hline Yellow & 92 a $\mathrm{A}$ & 91 a A & 79 a B & 76 a B \\
\hline Gray & $30 \mathrm{c} \mathrm{B}$ & $44 \mathrm{c} \mathrm{A}$ & $20 \mathrm{c} \mathrm{C}$ & $31 \mathrm{c} \mathrm{B}$ \\
\hline Mixed & $84 \mathrm{~b} \mathrm{~A}$ & $47 \mathrm{~b} \mathrm{~B}$ & $73 \mathrm{~b} \mathrm{~A}$ & $37 \mathrm{~b} \mathrm{~B}$ \\
\hline
\end{tabular}

${ }^{*}$ mean values followed by different lowercase letters, in the same column, are significantly different by Tukey's test at $5 \%$ probability.

in germination tests and in first germination count compared to a sample of seeds that were not separated by color (mixed), thus, seeds with red-yellow coat have superior physiological quality. Ferreira et al. (2020) concluded that the brownish-yellowish color of Brachiaria brizantha (cv. Marandu) seeds commercialized presented high physiological quality, compared to darker seeds.

In their research, TEIXEIRA et al. (2020) showed that the color of seeds directly influences their physiological quality, where green soybean seeds have lower viability and vigor than yellowish seeds, which causes a decrease in their physiological quality. In peas, Atak et al.(2008) verified that color shades of seeds analyzed, which are light, medium and dark green, influenced germination and seedling growth in the different wrinkled pea genotypes cv. Rondo, Carina and Jof, in which the dark green seeds showed the greatest vigor. These studies confirm that the color of the seed testa is an important indicator of maturity and; therefore, of physiological quality and that identification techniques should be studied.

Another important point is that the national standards for the production and marketing of coriander seeds require a minimum germination percentage of 65 and $70 \%$ for basic and certified seeds of first and second generation and S1 and S2 (MAPA, 2011). In this study, the germination percentage in yellowish seeds obtained values higher than the value required by the Ministry of Agriculture, Livestock and Supply - MAPA and; therefore, the sorting by color separated seeds of superior quality in the analyzed lots.

\section{CONCLUSION}

The parameters for separating coriander seeds by RGB image analysis, seeking a better selection of seeds according to color should be performed using the blue color scale. The germination test corroborates the result of seed sorting, where yellow seeds have higher physiological quality than brown/gray seeds.

\section{ACKNOWLEDGEMENTS}

To the Universidade Federal de Pelotas (UFPel) for the technical support in the development of this research, to the Conselho Nacional de Desenvolvimento Científico e Tecnológico (CNPq) and was financed in part by the Coordenação de Aperfeiçoamento de Pessoal de Nível Superior (CAPES), Brasil - Finance code 001.

\section{DECLARATION OF CONFLICT OF INTEREST}

The authors have no conflicting interests to declare.

\section{AUTHORS' CONTRIBUTION}

All authors contributed equally to the conception and writing of the manuscript. All authors critically reviewed the manuscript and approved the final version.

\section{REFERENCES}

ARAÚJO, A. P.et al.Ferramentas Computacionais para Biossistemas.Pelotas: Santa Cruz, 2015. p.162.

ATAK, M. et al.. Dark green colored seeds increase the seed vigor and germination ability in dry green pea (Pisum sativum L.). Pakistan Journal of Botany, v.40, n.6, p.2345-2354, 2008. Available from: <https://www.semanticscholar.org/paper/DARKGREEN-COLORED-SEEDS-INCREASE-THE-SEED-VIGORIN-Atak-Kaya/0e653de0dd505ecf922229a47657935dba19747f\#c iting-papers>. Accessed: Aug. 12, 2021.

BARBOSA, J. Z. et al. Uso de imagens digitais obtidas com câmeras para analisar plantas. Revista de Ciências Agrárias, Curitiba, v.39, n.1, p.15-24, 2016. Available from: $\quad<$ http://www.scielo.mec.pt/scielo.php?script $=$ sci_ 
arttext\&pid $=S 0871018 X 2016000100003 \& \operatorname{lng}=\mathrm{pt} \& \mathrm{nrm}=\mathrm{iso}>$. Accessed: Oct. 14, 2020. doi: 10.19084/RCA15006.

BRASIL. Ministério da Agricultura, Pecuária e Abastecimento Regras para análise de sementes. Ministério da Agricultura, Pecuária e Abastecimento. Secretaria de Defesa Agropecuária. Brasília, DF: Mapa/ACS, P.395. 2009.

COşUNER, Y.; KARABABA, E. Physical properties of coriander seeds (Coriandrum sativum L.). Journal Of Food Engineering, v.80, n.2, p.408-416,2007. Available from: <https://www. sciencedirect.com/science/article/abs/pii/S0260877406002226>. Acessed: Aug. 12, 2021. doi: 10.1016/j.jfoodeng.2006.02.042.

FERREIRA, A. S. et al.Coloração do tegumento e a relação com a qualidade fisiológica em sementes de Brachiaria brizantha. Brazilian Journal of Development, Curitiba, v.6, n.9, p.6605966069, 2020. Available from: <https://www.brazilianjournals.com/ index.php/BRJD/article/view/16276>Accessed: Oct. 14, 2020. doi: $10.34117 / \mathrm{bjdv} 6 \mathrm{n} 9-148$.

HEMENDER et al. Image Analysis: A Modern Approach to Seed Quality Testing. Current Journal of Applied Science and Technology, v. 27, p. 1-11, 2018.Available from: <http://www. sciencedomain.org/abstract/24348 $>$. Accessed: Oct. 14, 2020. doi: 10.9734/CJAST/2018/40945

JUSTINO, E. V. et al. Determinação da maturidade fisiológica de sementes de pimenta dedo de moça Capsicum baccatum var. pendulum. Horticultura Brasileira, v.33, n.3, p.324-331. 2015. Available from: $<$ http://www.scielo.br/scielo.php?script=sci arttext\&pid $=$ S $010205362015000300324 \& \operatorname{lng}=$ en\&nrm $=$ iso $>$. Accessed: Oct. 14, 2020. doi: 10.1590/S0102-053620150000300008.

MAPA - Ministério da Agricultura, Pecuária e Abastecimento, Secretaria de Defesa Agropecuária, Portaria SDA n ${ }^{\circ}$ 51, de 2 de março de 2011, Brasília: MAPA.

MONTEIRO, R. C. M. et al. Processamento de imagens para identificação de defeitos no arroz. In: ZUFFO, A.M. A produção do Conhecimento nas Ciências Agrárias e Ambientais. 4 ed. P. 298-306, 2019. Available from: <https://www.atenaeditora.com. br/post-artigo/13404>. Accessed: Oct. 14, 2020. doi: 10.22533/ at.ed.87619260427.

MONTEIRO, R. C. M. et al.Image processing to identify damage to soybean seeds. Ciência Rural, Santa Maria, Epub Dec 11, 2020. v.51, n.2, e20200107, 2021. Available from: <http:// www.scielo.br/scielo.php?script=sci_arttext\&pid=S0103- 84782021000200202\&lng=en\&nrm=iso $>$. Accessed: May, 10, 2021. doi: $10.1590 / 0103-8478 \mathrm{cr} 20200107$.

NASCIMENTO,W.M.etal.Harvesting andstorage of corianderseeds. Pesquisa Agropecuária Brasileira, Brasília, v.41,n.12,p.1793-1801, 2006. Available from: $<\mathrm{http} / / \mathrm{www} . s c i e l o . b r /$ scielo.php?script $=$ sci arttext\&pid $=\mathrm{S} 0100204 \mathrm{X} 2006001200015 \& \operatorname{lng}=\mathrm{en} \& \mathrm{nrm}=\mathrm{iso}>$. Accessed: Oct. 14, 2020. doi: 10.1590/S0100-204X2006001200015.

RIBEIRO, B. G. et al. Image analysis of coffee seeds submitted to the LERCAFE test. Acta Scientiarum, Agronomy. Maringá, v.38, n.3, p.355-361, 2016. Available from: <http://www.scielo. br/scielo.php?script $=$ sci arttext\&pid $=$ S1807862120160003003 $55 \& \operatorname{lng}=$ en\&nrm=iso $>$. Accessed: Sept. 08, 2020. doi: 10.4025/ actasciagron.v38i3.28268.

RIBEIRO, P. R. G. et al. Coloração do tegumento e qualidade fisiológica de sementes de trevo Branco. Informativo ABRATES, Londrina, v.23, n.2, p.51, 2013. Available from: <https://www.abrates.org. br/img/informations/73cc19c0-13b9-46dc-8b17-2cd0f519678a IA\%20 v23\%20n2\%20-\%20CBSementes.pdf $>$. Accessed: Aug. 12, 2021.

SANTANNA, M. G. F. et al. Content-based image retrieval towards the automatic characterization of soybean seed vigor. In: ACM SYMPOSIUM ON APPLIED COMPUTING, 29, 2014, Gyeongju Republic of Korea. SAC ' 14: Proceedings of the 29th Annual ACM [...]. [S. l.s. n.], 2014. p. 964-969. doi:10.1145/2554850.2555007.

SOUZA, T. V., et al. Época de colheita e qualidade fisiológica de sementes de coentro produzidas no norte de Minas Gerais. Revista Brasileira de Plantas Medicinais, Botucatu, v.13, p.591-597, may 2011. Available from: $<$ https://www.scielo.br/j//rbpm/a/3TrHf7F5q 4sJYpQZHQZBB3r/?format=pdf\&lang=pt $>$. Accessed: Aug. 11, 2021. doi: $10.1590 / \mathrm{S} 1516-05722011000500015$.

TEIXEIRA, S. B. et al. Green soybean seeds: effect on physiological quality. Ciência Rural, Santa Maria, v.50, n.2, e20180631, 2020. Available from: <http://www.scielo.br/scielo.php?script=sci_ar ttext\&pid $=S 010384782020000200201 \& \operatorname{lng}=$ pt\&nrm $=$ iso $>$. Accessed: Sept. 03, 2020. doi: 10.1590/0103-8478cr20180631.

VAZ, A. P. A. Coentro. Corumbá: Embrapa Pantanal, 2007. 1p. (Plantas medicinais, codimentares e aromáticas). (Boletim Eletrônico, 1).

WANDERLEY JÚNIOR, L. J. G; NASCIMENTO, W. M. Produção de sementes de coentro. 2008. Available from <http://www. abhorticultura.com.br/downloads/LuizJorgeProdsemcoentro.pdf $>$. Accessed: Sep. 03, 2019. 